\title{
Preconcentration of Ion Ni(II) using Ca-Alginate Modified Resin with Dimethylglyoxime as a Filler Material of Column
}

\author{
Aman Sentosa Panggabean*, Wirdhaningsih, Subur P. Pasaribu. \\ Department of Chemistry, Faculty of Sciences, Universitas Mulawarman, \\ Jalan Barong Tongkok Gunung Kelua, Samarinda, 75123. \\ *Corresponding author: amanspanggabean@yahoo.com
}

Received: April 2018; Revision: January 2019; Accepted: April 2020; Available online: May 2020

\begin{abstract}
The research about preconcentration of $\mathrm{Ni}(\mathrm{II})$ ions using $\mathrm{Ca}$-alginate resin modified with dimethylglyoxime (DMG) as a material filler of column has been done. The stage of preconcentration done by using the water sample was passed through the column, then eluted using $\mathrm{HNO}_{3}$. The amount of $\mathrm{Ni}(\mathrm{II})$ in the eluate was measured using atomic absorption spectrophotometer (AAS). The several important parameters in the preconcentration stage have been studied. The optimal condition at the stage of preconcentration $\mathrm{Ni}$ (II) ions was retention at $\mathrm{pH} 4$, the volume of sampel was $10 \mathrm{~mL}$, volume of $\mathrm{HNO}_{3}$ eluen was $4 \mathrm{~mL}$ at a concentration of 1.5 $\mathrm{M}$, with the retention of capacity value was $2.4657 \mathrm{mg} \mathrm{Ni}(\mathrm{II}) / \mathrm{g}$ resin. The analytical performance of this method is good, showed with repeatibility value as percentage of coefficient of variance value was $4.06 \%$, and can increase the limit detection of $\mathrm{Ni}(\mathrm{II})$ ions was 3.94 times, if compared to direct measurements with AAS. The method can be applied to determination of $\mathrm{Ni}$ (II) ions in the water samples from Mahakam river at port Samarinda with recovery percentage value was $>95 \%$, indicating that the matrix of samples not affect the results of measurements.
\end{abstract}

Keywords: AAS, Ca-alginate-DMG, Ni(II), preconcentration.

DOI:10.15408/jkv.v6i1.7700

\section{INTRODUCTION}

Heavy metal is widely used both directly and indirectly can pollute the environment if it exceeds specified limits and has a negative impact on life organism. The hazardous of heavy metals that often pollute the environment include mercury $(\mathrm{Hg})$, Lead $(\mathrm{Pb})$, Arsenic (As), Cadmium (Cd), Chromium (Cr) and Nickel (Ni). These heavy metals are known to be able to accumulate in the body of a microorganism and remain long-term as a poison (Rapp et al., 2017).

The preconcentration method most commonly used for trace metal ions is the solvent extraction method. The method has a disadvantage, because it requires expensive organic solvents, often has toxic properties and very dangerous (Naeemullah et al., 2012; Suwarsa et al., 2008). The preconcentration and separation techniques have a very important role in trace analysis of metal ions from various samples with very complex matrices. Preconcentration stages with sorption techniques not only increase the concentration of the analyte but also eliminate the matrix effect that can interfere with the analysis process (Miro and Frenzel, 2014).

Cation exchange resins can be used as a filler material of column in the preconcentration stages of heavy metal ions for sample analysis and provide solutions to the limitations of the sensitivity of instrument, in the determination of heavy metals at trace levels. The preconcentration method using cation exchange resins has advantages over other preconcentration methods, because the analyte loss factor can be minimized, the amount of resin used is small (0.1-0.5 g), can be regenerated and it can be used repeatedly for the same analysis (Panggabean et al., 2014).

Several studies on the use of preconcentration techniques in determination of metal ion such as; the characterization of $\mathrm{Ca}$ alginate based on ion exchange resins and the application toward $\mathrm{Pb}$ and $\mathrm{Zn}$ ions (Chen and Wang, 2001), transition metal ions (Fuks et al., 
2006), determination of $\mathrm{Cu}$ ions by using $\mathrm{Ca}-$ alginate microcapsules (Panggabean et al., 2012) and modification of Ca-alginate microcapsules with EDTA chelating in the preconcentration stages of $\mathrm{Pb}(\mathrm{II})$ metal ions (Sari et al., 2016), chitosan-1,5-diphenyl carbazide resins for analysis of $\mathrm{Cr}(\mathrm{VI})$ (Panggabean and Bohari, 2015), PSDVB-PAN resins for analysis of $\mathrm{Pb}$ (II) ions (Panggabean et al., 2010), and Cd(II) ions (Amran et al., 2011). The preconcentration of $\mathrm{Ni}$ (II) ions has been reported about the use of modified DMG adsorbents in magnetic nanoparticles with solid phase extraction techniques (Karimi and Kaffi, 2015), coprecipitation with $\mathrm{Al}(\mathrm{OH})_{3}$ (Thubkhum and Tangtreamjitmun, 2018), resins 1-(2pyridylazo)-2-naphthol modified in $\mathrm{SiO}_{2}$ nanoparticles (Kaur and Gupta, 2009), synthesis of PSDVB-DMG resins to adsorb $\mathrm{Ni}(\mathrm{II})$ ions (Darwin et al., 2016), and preconcentration of $\mathrm{Pb}, \mathrm{Cd}$ and $\mathrm{Ni}$ ions in the Cikapundung river Bandung samples by extraction methods using chelating reagents (Koesmawati et al., 2017).

Based on the description above, in this research a Ca-alginate microcapsule resin modified with dimethylglyoxime (DMG) was made as a filler material of column in the preconcentration stage of $\mathrm{Ni}$ (II) ions, which had not been previously reported. In this research, several stages of determining the optimum composition of Ca-alginate-DMG were made, optimization in the preconcentration stage, the analytical performance, and it's application in the determination of $\mathrm{Ni}(\mathrm{II})$ ions in water samples from nature.

\section{MATERIALS AND METHOD Instrumentation and Materials}

The instruments used in this research are Atomic Absorption Spectrophotometer (GBC Avanta 6000), laboratory glassware, analytical balance, hot plate, cuvette, spatula, micro pipette, glass beaker, stopwatch, plastic film bottle, clamps, stative and glass column (1 $\mathrm{cm}$ i.d x $30 \mathrm{~cm}$ length).

The materials used are $\mathrm{CaCl}_{2}, \mathrm{Na}-$ alginate, dimethylglyoxime (DMG), $\mathrm{NiSO}_{4} \cdot 6 \mathrm{H}_{2} \mathrm{O}, \mathrm{HNO}_{3}$ (E'Merck), Universal $\mathrm{pH}$, filter paper, aquabides and samples water was taken from dam and the Mahakam river at port Samarinda, East Kalimantan.

\author{
Manufacturing of Ca-Alginate- \\ Dimethylglyoxime (DMG) Resin
}

A total of $50 \mathrm{~mL}$ of $0.3 \mathrm{M} \mathrm{CaCl}_{2}$ solution was put into a glass beaker, added DMG powder as much as $0.05 \mathrm{~g}(0.1 \% \mathrm{w} / \mathrm{v})$ and stirred until homogeneous. $1 \% \mathrm{Na}$-alginate solution $(1 \mathrm{~g} \mathrm{Na}-$ alginate dissolved in $100 \mathrm{~mL}$ aquabides) in the burette, added dropwise to $\mathrm{CaCl}_{2}$ solution while stirring with magnetic stirrer to form $\mathrm{Ca}$ alginate-DMG microcapsules. The Ca-alginateDMG microcapsules obtained were dried at room temperature \pm 24 hours. Furthermore, the resins can be determined that the retention toward Ni(II) ions (Sari et al., 2016).

\section{Optimization of Ca-Alginate-DMG Resin by Batch Method (Effects of pH)}

$0.1 \mathrm{~g}$ of Ca-alginate-DMG resin was immersed in aquabides, whose $\mathrm{pH}$ of solution was adjusted to a variation of 2-8. The resin was dried and added with a standard solution of $\mathrm{Ni}$ (II) $10 \mathrm{mg} / \mathrm{L}$ and soaked for \pm 24 hours. Filtered and the filtrate was measured using AAS.

\section{Determination of the Retention Capacity of Ca-Alginate-DMG Resin toward Ni(II) Ions}

$0.1 \mathrm{~g}$ of $\mathrm{Ca}$-alginate-DMG resin was immersed in $10 \mathrm{~mL}$ of $\mathrm{Ni}$ (II) solution, that the concentration was varied $0.5-80 \mathrm{mg} / \mathrm{L}$ for \pm 24 hours. Filtered and the filtrate was measured using AAS (Panggabean et al., 2014).

\section{Optimization of Ca-Alginate-DMG Resin Preconcentration by Column Method Effects of Acid Concentration}

Ca-Alginate-DMG resin that has been conditioned at the optimum $\mathrm{pH}$ was inserted into the column and added with $10 \mathrm{~mL}$ of $1 \mathrm{mg} / \mathrm{L}$ $\mathrm{Ni}$ (II) of standard solution, subsequently eluted with $5 \mathrm{~mL}$ of $\mathrm{HNO}_{3}$ with a concentration variation of $0.5-3 \mathrm{M}$. The filtrate was measured using AAS.

\section{Effects of Ni(II) Ion Volume}

Ca-alginate-DMG resin that has been conditioned at the optimum $\mathrm{pH}$ was inserted into the column and added with $1 \mathrm{mg} / \mathrm{L} \mathrm{Ni(II)}$ standard solution, that the volume varied 2-10 $\mathrm{mL}$. The $\mathrm{Ni}$ (II) ion which is retained in each volume variation is then eluted with $5 \mathrm{~mL}$ $\mathrm{HNO}_{3}$. The filtrate was measured using AAS. 


\section{Effect of Acid Volume}

Ca-alginate-DMG resin that has been conditioned at the optimum $\mathrm{pH}$ was inserted into the column and added with to the optimum volume of $1 \mathrm{mg} / \mathrm{L} \mathrm{Ni(II)} \mathrm{standard} \mathrm{solution.} \mathrm{The}$ $\mathrm{Ni}$ (II) was retained subsequently eluted with $\mathrm{HNO}_{3}$, at the varied of volume was 3-10 mL. The filtrate was measured using AAS (Panggabean and Bohari, 2015).

\section{Analytical Performance Linearity}

In this research, linearity was determined by preparing a standard $\mathrm{Ni}$ (II) series solution with a concentration of $0.05-1 \mathrm{mg} / \mathrm{L}$, with the optimum conditions and the same procedure as in the optimization of Ca-alginateDMG resin by the batch method above. Each absorbance was determined using AAS. The regression line equation was obtained by plotting the absorbance against the concentration of $\mathrm{Ni}(\mathrm{II})$.

\section{Precision (Repeatibility)}

Repeatability was determined by measuring the absorbance of a $0.2 \mathrm{mg} / \mathrm{L} \mathrm{Ni}$ (II) standard solution with AAS repeatedly $(\mathrm{n}=10)$, at the optimum conditions and the same procedure as above.

\section{Limit of detection (LOD)}

LOD can be determined using a calibration curve equation obtained through a linear regression line from the calibration curve (Miller and Miller, 1991).

\section{Application of Sample Waters from Nature The Percentage of Recovery}

Determinaton of the effect of the matrix on the measurement of $\mathrm{Ni}$ (II) ions in the water samples from nature, it is done by determining of the percentage of recovery (\% recovery), using the spike method. In this spike method, a certain amount of the volume $\mathrm{Ni}$ (II) standard solution was pipetted and then added to the water sample. The absorbance of the spike solution was determined by using AAS with the optimum conditions and the same procedure as above.

\section{RESULTS AND DISCUSSION Optimization of Ca-Alginate-DMG Resin by Batch Method \\ Effects of $\mathbf{p H}$}

The retention of each metal ion against a particular resin is strongly influenced by the $\mathrm{pH}$ of the resin or sample solution. Each metal ion is optimum at only a certain $\mathrm{pH}$ (Panggabean et al., 2010). Measurement of the effect of $\mathrm{pH}$ variations, of Ca-alginate-DMG resin by using batch method, can be seen in Fig. 1.

Ca-alginate-DMG resin has been conditioned with a good $\mathrm{pH}$ absorption results at pH 3-5 (Fig. 1), can absorb Ni(II) ions above 98\%. While the $\mathrm{pH}$ greater than 5 and less than $\mathrm{pH} 3$, a greater number of $\mathrm{H}^{+}$and $\mathrm{OH}^{-}$ions (very acidic or very base) will damage $\mathrm{Ca}$-alginate because the resin will return forming back to gel, and the retention is not optimal (Mørch et al., 2006). The optimum $\mathrm{pH}$ used in further work was $\mathrm{pH} 4$.

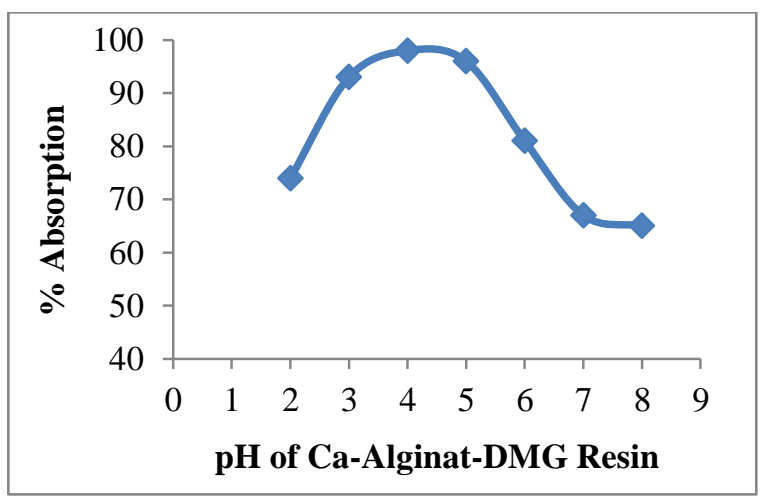

Figure 1. Effect of pH of Ca-alginate-DMG resin in the absorption of $\mathrm{Ni}$ (II).

\section{Ca-Alginate-DMG Retention Capacity}

Retention capacity is a measure of the ability of the Ca-alginate-DMG resin to retain $\mathrm{Ni}$ (II) ions (Amran et al., 2011). The more amount of $\mathrm{Ni}$ (II) ions absorbed, produce the higher value of retention capacity. Retention capacity analysis can be done by batch method, the measurement results can be seen in Fig. 2 .

The retention capacity of Ca-alginateDMG for $\mathrm{Ni}(\mathrm{II})$ metal ions can be determined using line intersection of two curves (Fig 2.), where the meeting point is the retention capacity of Ca-alginate-DMG resin (Panggabean et al., 2012). The intersection of the two lines is the retention capacity of Ca-alginate-DMG was $2.4657 \mathrm{mg} / \mathrm{g}$ resin. The result of this amount 
was means that every $1 \mathrm{~g}$ of Ca-alginate-DMG resin can retain $2.4657 \mathrm{mg}$ of $\mathrm{Ni}(\mathrm{II})$ ion.

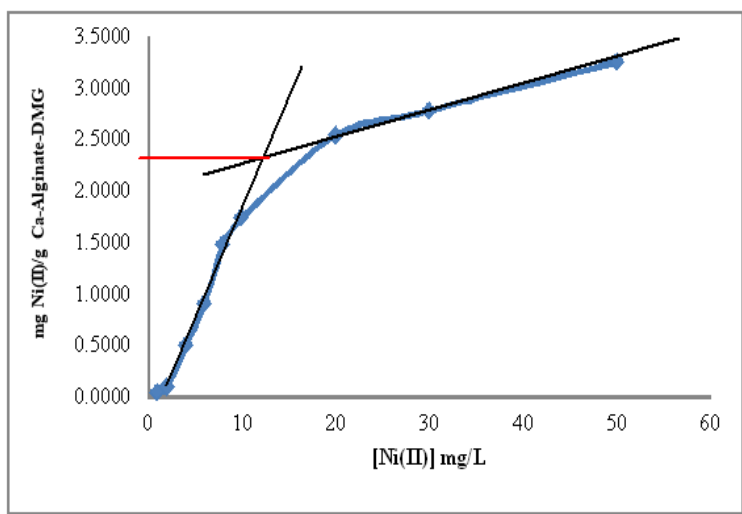

Figure 2. Retention capacity of Ca-Alginate-DMG resins toward $\mathrm{Ni}$ (II) ions

\section{Optimization of Ca-Alginate-DMG Resin Preconcentration by Column Method Effects of Concentration and Volume of Acid as Eluent}

The next preconcentration stage is effect of concentration and volume of acid as eluent. $\mathrm{HNO}_{3}$ was used as an eluent to release the $\mathrm{Ni}$ (II) ion that is retained in the Ca-alginate-DMG resin. The concentration and volume of the eluent must be optimized because it greatly influences the analytical performance of the measurement results and was expected to not damage the resin in the column (Panggabean et al., 2014). The measurement results can be seen in Fig 3.

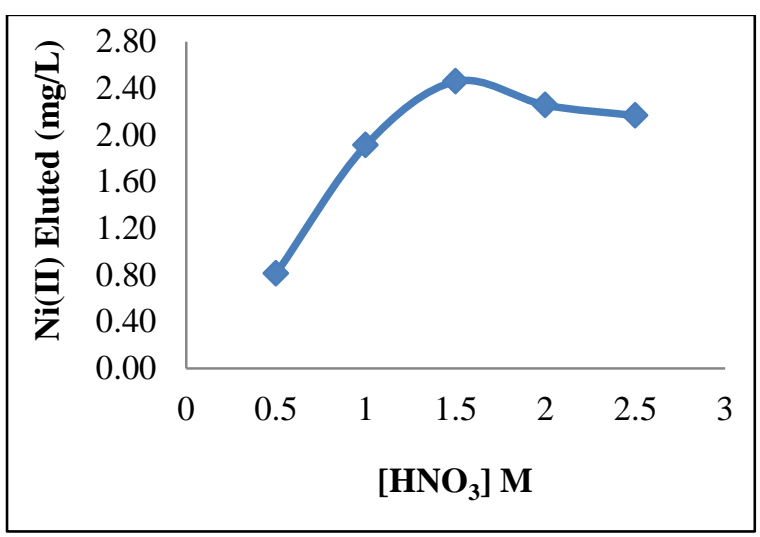

Figure 3. Effect of $\mathrm{HNO}_{3}$ concentration as eluent

The optimum concentration of $\mathrm{HNO}_{3}$ as eluent was $1.5 \mathrm{M}$ (Fig. 3). While the concentration of $\mathrm{HNO}_{3}$ eluent above $2 \mathrm{M}, \mathrm{Ni}$ (II) ion which eluted will be decrease. This is due to the higher concentration of $\mathrm{HNO}_{3}$, will be able the damage of Ca-alginate DMG resin, and the retention of the resin is not optimal. For the next stage the optimum volume of the $1.5 \mathrm{M} \mathrm{HNO}_{3}$ eluent was determined, with used the same conditions as determining the optimum eluent concentration. The measurement results can be seen in Fig 4.

Based on Fig. 4, it can be seen in the $\mathrm{HNO}_{3}$ eluent volume at the begining from $2 \mathrm{~mL}$, it has been able to optimally elucidate the $\mathrm{Ni}$ (II) ion which was retented by $\mathrm{Ca}$-alginate-DMG resin. Furthermore, at the volumes higher than 4 $\mathrm{mL}$, the $\mathrm{Ni}$ (II) ions retain did indeed increase, but the amount obtained was not significantly different from the $4 \mathrm{~mL}$ eluent volume. This is due to the maximum amount of $\mathrm{Ni}$ (II) eluted at the $4 \mathrm{~mL}$ eluent volume. For the next stage of the research used $4 \mathrm{~mL}$ of $\mathrm{HNO}_{3}$ volume as eluent.

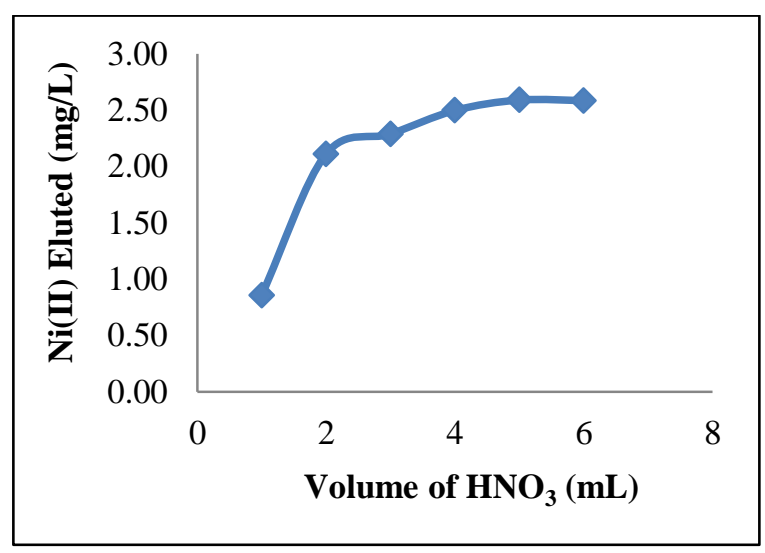

Figure 4. Effect of volume $\mathrm{HNO}_{3}$ as eluent

\section{Effects of Ni(II) Volume}

The number of sample volumes of $\mathrm{Ni}$ (II) ions needs to be determined to find out the optimum volume of $\mathrm{Ni}$ (II) ions that are retain by resins. The concentration of $\mathrm{Ni}(\mathrm{II})$ ions used remains $1 \mathrm{mg} / \mathrm{L}$, where the volume of $\mathrm{Ni}(\mathrm{II})$ ions is varied from $1-10 \mathrm{~mL}$ and the concentration eluent $\mathrm{HNO}_{3}$ was $1.5 \mathrm{M}$ with volume was $4 \mathrm{ml}$. Furthermore, the elution results are measured by AAS. The measurement results can be seen in Fig 5 .

Based on Fig 5. it can be seen that the eluted $\mathrm{Ni}$ (II) ion increases with increasing volume of $\mathrm{Ni}$ (II) ions which are inserted into the column. This means that the increase in measurement of the number of $\mathrm{Ni}$ (II) ions which was retained is directly proportional to the increasing volume of the sample standard solution. For the effectiveness of the preconcentration stage, the volume of the $10 \mathrm{~mL}$ 
$\mathrm{Ni}$ (II) ions solution is used for the next stage of this research.

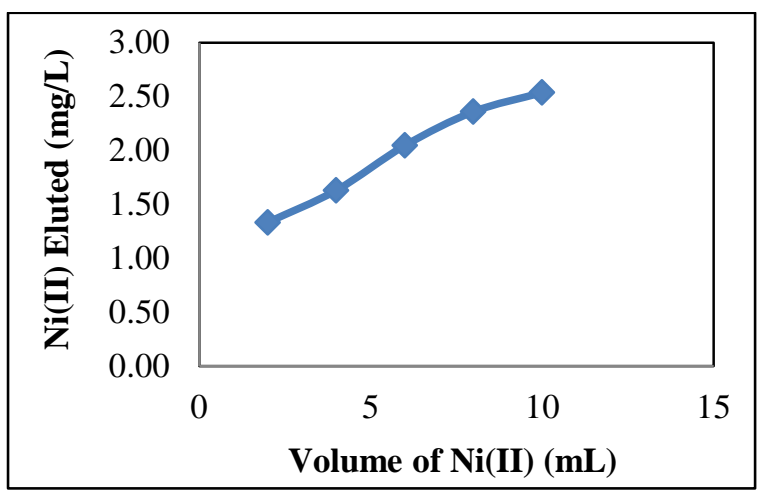

Figure 5. Effect of Ni(II) ions volume

\section{Analytical Performance Linearity}

Linearity of analytical methods is the ability to find out the results of the analysis directly and in proportion to the concentration of analytes in a sample with a predetermined range aimed at proving a linear relationship between the actual (theoretical) substance concentration and the instrument response. Linearity or the correlation tendency between two variables is usually expressed in the correlation coefficient (r) and was said to be good if the value is $\approx 1$ (Garfield, 1991; Miller and Miller, 1991).

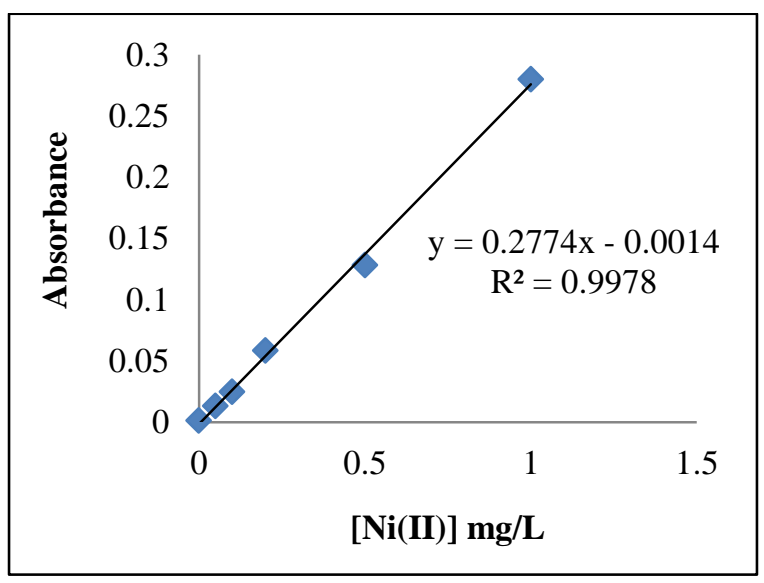

Figure 6. Calibration curve of Ni(II) standard.

Based on the results of measurements, the calibration curve obtained for the $\mathrm{Ni}$ (II) ions after being passed into a column containing $\mathrm{Ca}$ alginate-DMG resin, the line equation $\mathrm{y}=$ $0.277 \mathrm{x}-0.001$ with a correlation coefficient $\left(\mathrm{R}^{2}\right)$ $=0.997$ was obtained (Fig. 6). The results of this study shows, the measurements can be made in the trace level area $(\mu \mathrm{g} / \mathrm{L})$, because the linearity range obtained is at intervals of 50$1000 \mu \mathrm{g} / \mathrm{L}$. The concentration range can be used as a measurement work area in determinination of $\mathrm{Ni}$ (II) ion concentrations in in the sample solution. Furthermore, this regression equation is used to measure sample concentration.

\section{Precision}

Precision illustrates the repeatibility of measurements, namely the closeness between one data value with another data obtained using the same of solution, equipment, method, time and analyst. In this research, the repeated of measurements of a concentration of $\mathrm{Ni}$ (II) ion has been done, at the under optimum conditions. Repetition of measurements taken 10 times, and expressed in a percentage of coefficient of variance $(\% \mathrm{CV})$. The \% $\mathrm{CV}$ obtained in this research was $4.06 \%$, for the concentration of $0.2 \mathrm{mg} / \mathrm{L} \mathrm{Ni}$ (II) standard solution. The method was said to have good precision if the \% CV wass $\leq 5 \%$ (Garfield, 1991; Miller and Miller, 1991).

The value of $\% \mathrm{CV}$ obtained was compared with 2/3 \% CV Horwitz. The precision of a method will qualify if the $\% \mathrm{CV}$ obtained from the experiment is less than $2 / 3$ CV Horwitz. The \% CV of the experimental was $4.06 \%$ is smaller than the value of $2 / 3 \% \mathrm{CV}$ Horwitz are $17.52 \%$, and it can be said the method of developed has a good precision (Garfield, 1991).

\section{Limit of Detection (LOD)}

The limit of detection states the smallest minimum concentration or mass that can still be detected by an analysis method with a high level of confidence (Miller and Miller, 1991). The value of LOD can be estimated the minimum number of sample concentrations needed in an analysis process as well as the search for new methods or the development of the old methods by comparing the detection limit with the previous method.

Determination of the LOD value is done by the linearity method by using the intercept line regression equation (Garfield, 1991; Miller and Miller, 1991). Based on the result of this research obtained, to determine the linearity measurement of $\mathrm{Ni}$ (II) directly with AAS obtained a regression line $y=0.091 x+0.0076$, the LOD value obtained was $0.1781 \mathrm{mg} / \mathrm{L}$. After preconcentration, the regression line of measurements are $\mathrm{y}=0.227 \mathrm{x}-0.001$, and 
obtained the LOD value was $0.0451 \mathrm{mg} / \mathrm{L}$. It can be concluded that the preconcentration technique developed can increased the LOD measurement of 3.94 times, when compared with direct measurement of $\mathrm{Ni}(\mathrm{II})$ with AAS.

\section{Application of natural samples and the influence of matrices}

The final of the aims of this research is to apply the preconcentration technique developed for the analysis of $\mathrm{Ni}(\mathrm{II})$ ions in water samples taken from nature, using $\mathrm{Ca}$-alginate-
DMG resin as a filler material of column. In this research, the determination of \% recovery, performed by the spike method. In this method, water samples and blank are added with a certain amount of standard analyte solution whose concentration is known (Panggabean et al., 2014). The concentration of the analyte is determined in both the water samples and blank, and $\%$ recovery was obtained. The results of the research were obtained in the sample from Mahakan River and dam water, and can be seen in Table 1.

Table 1. \% Recovery value of Ni(II) ions

\begin{tabular}{lccc}
\hline \multirow{2}{*}{ Sample } & \multicolumn{2}{c}{$\mathbf{N i ( I I ) , \mu \mathbf { ~ L } ^ { - 1 }}$} & \multirow{2}{*}{ \% Recovery } \\
\cline { 2 - 4 } & Added & Found & - \\
Mahakam river & 0 & $148.4 \pm 16.5$ & $96.26 \pm 1.16$ \\
\multirow{2}{*}{ Dam } & 200 & $339.8 \pm 31.6$ & - \\
\hline
\end{tabular}

The $\%$ recovery results obtained for the analysis of the water samples from dam and Mahakam river at port of Samarinda gave a value $>95 \%$, indicating that the accuracy of the method developed was good (Miller and Miller, 1991). Based on this results, can be concluded the preconcentration technique was developed can be used for the analysis of $\mathrm{Ni}$ (II) ions for water samples in nature, because the influence of the matrix contained in the sample can be simplified and does not interfere with the measurement results.

\section{CONCLUSION}

Dimethylglyoxime (DMG) can be modified to form Ca-alginate-DMG microcapsules and can be used as a filler material of column in the preconcentration stages of $\mathrm{Ni}$ (II) ions in water samples. The optimum conditions of the preconcentration technique obtained were $\mathrm{Ni}$ (II) ions which could be retained at $\mathrm{pH} 4$, retention capacity was $2.4657 \mathrm{mg} \mathrm{Ni}(\mathrm{II}) / \mathrm{g}$ resin, the concentrations and volumes of $\mathrm{HNO}_{3}$ as eluents were $1.5 \mathrm{M}$ and 4 $\mathrm{mL}$ respectively, and the volume of $\mathrm{Ni}(\mathrm{II})$ was $10 \mathrm{~mL}$. The analytical performance obtained is very good which is shown the measurement of parameters such as precision with a $\% \mathrm{CV}$ value was $4.06 \%$. The LOD value was $0.0541 \mathrm{mg} / \mathrm{L}$ and can increase the LOD of $\mathrm{Ni}$ (II) ions of 3.94 times, if compared to direct measurements with AAS. The preconcentration technique has been applied for the analysis of $\mathrm{Ni}(\mathrm{II})$ ions in water samples from the environment with a \% recovery value of $>95 \%$, indicating the method can be used for analysis of $\mathrm{Ni}(\mathrm{II})$ ions in the sample at the trace levels.

\section{REFERENCES}

Amran MB, Panggabean AS, Sulaeman A, Rusnadi M. 2011. Preparation of a chelating resin and its application as a preconcentration system for determination of cadmium in river water by flow injection analysis. Int. J. Env Res. II:531-536.

Chen JP, Wang L. 2001. Characterization of a Caalginate based ion-exchange resin and its application in lead, copper, and zinc removal. Separation Science and Technology. 36(16): 3617-3637.

Darwin C, Panggabean AS, Alimuddin. 2016. Sintesis resin pengkhelat polystirena divinyl benzena-dimetilglioksima dan kemampuan adsorpsi terhadap ion logam $\mathrm{Ni}(\mathrm{II}) . J$. Atomik. 2(1): 128-133.

Fuks L, Filipiuk D, Majdan M. 2006. Transition metal complexes with alginate biosorbent. $J$. of Mol. Struct. 792-793:104-109.

Garfield FM. 1991. Quality Assurance Principles for Analytical Laboratories. AOAC International, USA. 
Karimi MA, Kafi M. 2015. Removal, preconcentration and determination of $\mathrm{Ni}(\mathrm{II})$ from different environmental samples using modified magnetite nanoparticles prior to flame atomic absorption spectrometry. Arabian Journal of Chemistry. 8: 812-820.

Kaur A, Gupta U. 2009. Preconcentration of Nickel using chemically modified silica nanoparticles. Eurasian J. Anal. Chem. 4(2): 175-183.

Koesmawati TA, Moelyo M, Rizqiani A, Tanuwidjaja S. 2017. Pre-concentration of $\mathrm{Pb}, \mathrm{Cd}$, and $\mathrm{Ni}$ in river water using back extraction method. In IOP Conf. Series: Earth and Environmental Science. 60(1): 012-021.

Miller JC, Miller JN. 1991. Statistika Untuk Kimia. Edisi Kedua. Bandung (ID): ITB Press.

Miro M, Frenzel W. 2014. Flow-through sorptive preconcentration with direct optosensing at solid surfaces for trace ion analysis. Trends in Analytical Chemistry. 23(1): 49-53.

Mørch A, Donati I, Strand LB, Skajak-Braek G. 2006. Effect of $\mathrm{Ca}^{2+}, \mathrm{Ba}^{2+}$, and $\mathrm{Sr}^{2+}$ on alginate microbeads. Biomacromolecules. 7: 1471-1480.

Naeemullah, Kazi TG, Shah F, Afridi HI, Khan S, Arian SS, Brahman KD. 2012. A green preconcentration method for determination of cobalt and lead in fresh surface and waste water samples prior to flame atomic absorption spectrometry. Journal of Analytical Methods in Chemistry. 20: 1-8.

Panggabean AS, Pasaribu SP, Bohari, Nurhasanah. 2014. Preconcentration of Chromium (VI) at trace levels using acid alumina resin with column method.Indones. J. Chem. Sci.14(1): 51-56.
Panggabean AS, Pasaribu SP, Sari IYL. 2012. Prakonsentrasi ion $\mathrm{Cu}(\mathrm{II})$ menggunakan resin berbasis mikrokapsul Ca-Alginat secara off-line dengan metode kolom. Chem. Prog. 5(2): 70-76.

Panggabean AS, Pasaribu SP, Amran MB. 2010. Chelating resin as preconcentration system for the determination of trace lead based on flow injection analysis method. Proc. Int. Conf. Math. Nat. Sci. Bandung.

Panggabean AS, Yusuf B. 2015. Determination of Chromium (VI) by using chitosan-1,5diphenyl carbazide resin modified at the preconcentration system with colomn method. Int. J. Pharma and Bio Sci.6(3): 101-111.

Rapp I, Schlosser C, Rusiecka D, Gledhill M, Achterberg EP. 2017. Automated preconcentration of $\mathrm{Fe}, \mathrm{Zn}, \mathrm{Cu}, \mathrm{Ni}, \mathrm{Cd}, \mathrm{Pb}$, $\mathrm{Co}$, and $\mathrm{Mn}$ in seawater with analysis using high-resolution sector field inductivelycoupled plasma mass spectrometry. Anal. Chim. Acta. 976(11): 1-13.

Sari RJ, Panggabean AS,Erwin. 2016. Pemanfaatan resin $\mathrm{Ca}$-alginat termodifikasi dengan etilen diamina tetraasetat (EDTA) dalam tahapan prakonsentrasi ion $\mathrm{Mn}(\mathrm{II})$ berbasis metode kolom. J. Atomik. 1(1): 28-35.

Suwarsa S, Buchari, Panggabean AS. 2008. Pengembangan metode prakonsentrasi dengan teknik injeksi alir untuk analisis $\mathrm{Cu}^{2+}$ dan $\mathrm{Pb}^{2+}$ dalam air aliran sungai Citarum dan waduk Saguling. J. Mat. dan Sains. 13: 1-6.

Thubkhum N, Tangtreamjitmun. 2018. Determination of Nickel by flame atomic absorption spectrometry after preconcentration by coprecipitation with aluminium hydroxide. Anal. Sci. 34: 849851. 